\title{
ОПТИМІЗАЦІЯ ПРОГНОЗУВАННЯ РОЗВИТКУ МОРФОЛОГІЧНИХ ПОРУШЕНЬ ПРИ ЕКСПЕРИМЕНТАЛЬНІЙ ГОСТРІЙ ІШЕМІЇ-РЕПЕРФУЗІЇ НА ОСНОВІ ПОЄДНАНИХ ЗМІН БІОХІМІЧНИХ ПОКАЗНИКІВ ЗА ДОПОМОГОЮ КОРЕЛЯЦІЙНОГО АНАЛІЗУ ТА НЕЙРОМЕРЕЖЕВОЇ КЛАСТЕРИЗАЦІЇ
}

\author{
П. Р. Сельський, А. Т. Телев'як, Т. О. Вересюк, Б. П. Сельський
}

Тернопільський національний медичний університет імені І. Я. Горбачевського МОЗ України

У роботі запропоновано методику оптимізації прогнозування розвитку ішемічних порушень при експериментальній гострій ішемії-реперфузії на основі поєднаних змін біохімічних показників. Підхід ґрунтується на обчисленні коефріцієнтів кореляції та використанні нейромережевої кластеризації. Експериментальна модель ішемічно-реперсузійного ураження представлена п'ятьма групами щурів із термінами реперфузії 1 і 2 години, 1 доба, 7 та 14 діб (по 18 тварин у кожній). Контрольна група нараховувала 15 тварин. За допомогою кореляційного аналізу виявлено середньої сили прямий кореляційний зв'язок між показниками пересічної площі м'язових волокон і показниками аланінамінотрансферази $(+0,5)$ та аспартатамінотрансферази $(+0,5)$, що свідчить про переважання процесів катаболізму в ішемізованій м'язовій тканині. Для більш глибокого аналізу та кластеризації показників досліджуваних груп із метою оптимізації прогнозування перебігу ішемічно-реперфузійного ураження застосовано нейромережевий підхід із використанням надбудови NeuroXL Classifier для програми Microsoft Excel. Встановлено найбільше прогностичне значення щодо тяжкості морфологічних порушень у ранньому реперсрузійному періоді за даними нейромережевої кластеризації поєднаних змін рівня креатиніну та аланінамінотранссрерази.

Ключові слова: гостра ішемія-реперфузія, морфологічні зміни, кореляційний аналіз, нейромережева кластеризація.

\section{OPTIMIZATION OF PREDICTION OF THE DEVELOPMENT OF MORPHOLOGICAL DISORDERS AFTER EXPERIMENTAL ACUTE ISCHEMIA-REPERFUSION BASED ON COMBINED CHANGES IN BIOCHEMICAL PARAMETERS BY MEANS OF CORRELATION ANALYSIS AND NEURAL NETWORK CLUSTERING}

\author{
P. R. Selskyy, A. T. Televiak, T. O. Veresiuk, B. P. Selskyy \\ Ivan Horbachevsky Ternopil National Medical University
}

\begin{abstract}
Background. The study proposes a method for optimizing the prediction of the development of ischemic disorders by experimental acute ischemia-reperfusion based on combined changes in biochemical parameters. The approach is based on the calculation of correlation coefficients and the use of neural network clustering.

The aim of the study is to propose a method for optimizing the prediction of the severity of morphological disorders in the early reperfusion period after experimental acute ischemia-reperfusion based on combined changes in biochemical parameters by means of correlation analysis and neural network clustering.

Materials and Methods. The experimental model of ischemic-reperfusion lesion is represented by five groups of rats with reperfusion terms of 1 and 2 hours, 1 day, 7 and 14 days (18 animals in each group). The control group consisted of 15 animals. Acute ischemia was caused by the imposition of SWAT rubber bundles on the hind limbs of rats for $2 \mathrm{~h}$ under thiopental sodium anesthesia. Histological and morphometric examination of skeletal muscle was conducted at the Department of Pathological Anatomy with the section course and forensic medicine of the I. Gorbachevsky Ternopil National Medical University by conventional methods. Statistical data processing with calculating of Mann-Whitney's U-criterion and Spearman's correlation coefficient was performed using the Microsoft Excel (2010) software package according to conventional methods. For a deeper analysis and clustering of the study groups, in order to optimize the prognosis of ischemia-reperfusion lesions, a neural network approach was used by using the Neuro XL Classifier add-in for Microsoft Excel.

Results and Conclusions. By means of correlation analysis, the average strength of the direct correlation between the indicators of the average area of muscle fibers and the indices of alanine aminotransferase $(+0,5)$ and aspartate aminotransferase $(+0,5)$ is revealed, which indicates the predominance of catabolism processes in ischemic muscle tissue. According to neural network clustering the greatest prognostic value for the detection of severity of morphological disorders in the early reperfusion period have the combined changes in creatinine and alanine aminotransferase levels.
\end{abstract}

Key words: acute ischemia-reperfusion, morphological changes, correlation analysis, neural network clustering.

(c) П. Р. Сельський, А. Т. Телев’як, Т. О. Вересюк, Б. П. Сельський 


\title{
ОПТИМИЗАЦИЯ ПРОГНОЗИРОВАНИЯ РАЗВИТИЯ МОРФОЛОГИЧЕСКИХ НАРУШЕНИЙ ПРИ ЭКСПЕРИМЕНТАЛЬНОЙ ОСТРОЙ ИШЕМИИ- РЕПЕРФУЗИИ НА ОСНОВАНИИ СОЧЕТАННЫХ ИЗМЕНЕНИЙ БИОХИМИЧЕСКИХ ПОКАЗАТЕЛЕЙ ПРИ ПОМОЩИ КОРРЕЛЯЦИОННОГО АНАЛИЗА И НЕЙРОСЕТЕВОЙ КЛАСТЕРИЗАЦИИ
}

\author{
П. Р. Сельский, А. Т. Телевяк, Т. О. Вересюк, Б. П. Сельский
}

Тернопольский национальный медицинский университет имени И. Я. Горбачевского МЗ Украины

\begin{abstract}
В работе предложено методику оптимизации прогнозирования развития ишемических нарушений при экспериментальной острой ишемии-реперфузии на основании сочетанных изменений биохимических показателей. Подход базируется на вычислении коэффициентов корреляции и использовании нейросетевой кластеризации. Экспериментальная модель ишемически-реперфузионного поражения представлена пятью группами крыс со сроками реперфузии 1 и 2 часа, 1 сутки, 7 и 14 суток (по 18 животных в каждой). Контрольная группа насчитывала 15 животных. При помощи корреляционного анализа выявлено средней силы прямую корреляционную связь между показателями аланинаминотрансреразы (+0,5) и аспартатаминотрансфреразы (+0,5), что свидетельствует о преобладании процессов катаболизма в ишемизированной мышечной ткани. Для более глубокого анализа и кластеризации показателей исследуемых групп с целью оптимизации прогнозирования течения ишемически-реперфузионного поражения применен нейросетевой подход с использованием надстройки NeuroXL Classifier для программы Microsoft Excel. Наибольшее прогностическое значение для определения тяжести морфологических нарушений в раннем реперфузионном периоде по данным нейросетевой кластеризации имеют сочетанные изменения уровня креатинина и аланинаминотранссеразы.
\end{abstract}

Ключевые слова: острая ишемия-реперфузия, морфологические изменения, корреляционный анализ, нейросетевая кластеризация. 
Вступ. Ефективне використання інформаційних методик дає можливість суттєво підвищити якість та забезпечити комплексний підхід у наукових медичних дослідженнях, особливо в царині морфології, де необхідно здійснювати аналіз значної за обсягом цифрової інформації. Численні дослідження спрямовані на вирішення проблем упровадження інноваційних інформаційних технологій [1-3], проте не до кінця вирішеною залишається проблема їх використання в експериментальній медицині. При цьому важливою стає оптимізація прогнозування розвитку патологічних процесів із метою ефективного прикладного використання на практиці. Особливо актуальним $є$ прогнозування морфологічних порушень тканин при гострій ішемії-реперфузії у результаті травм кінцівок та розвитку турнікетного синдрому, що залишається одним із найпоширеніших видів пошкоджень як у військовій, так і в цивільній медицині [4-9].

Мета роботи: запропонувати методику оптимізації прогнозування тяжкості морфологічних порушень при експериментальній гострій ішеміїреперфузії на основі поєднаних змін біохімічних показників за допомогою кореляційного аналізу та нейромережевої кластеризації.

Матеріал і методи. Відповідно до мети та завдань дослідження тварини були розділені на шість експериментальних груп. Експериментальна модель раннього ішемічно-реперфузійного періоду представлена групами тварин із термінами реперфузії 1 година, 2 години та 1 доба, а модель пізнього ішемічно-реперфузійного періоду — групами тварин із термінами реперфузії 7 та 14 діб (по 18 тварин у кожній групі). Для проведення порівняльного аналізу виділена інтактна група тварин (15 тварин). Гостру ішемію спричиняли шляхом накладання гумових джгутів SWAT на задні кінцівки щурів протягом 2 годин під тіопентал-натрієвим знеболюванням. Гістологічне дослідження проводилося на кафедрі патологічної анатомії з секційним курсом та судовою медициною Тернопільського національного медичного університету імені І. Я. Горбачевського MO3 України за загальноприйнятими методиками [10]. Біохімічні зміни, а саме, показники загального білірубіну, тригліцеридів, холестерину, креатиніну, загального білка, лужної фосфатази та рівень трансаміназ (АлАТ, АсАТ) визначали в сироватці крові у кожній піддослідній групі.

Статистична обробка матеріалу проводилася з використанням пакета програм Microsoft Excel (2010). Перевірку показників на нормальний розподіл здійснювали за тестом КолмогороваСмірнова. Статистична значущість різниці між середніми арифметичними оцінювалася за непараметричним критерієм Манна-Уітні. При порівнянні однотипних груп проводився кореляційний аналіз з врахуванням коефіцієнта кореляції за Спірменом (r).

Для більш глибокого аналізу та кластеризації показників досліджуваних груп із метою оптимізації прогнозування перебігу ішемічно-реперфузійного ураження застосовано нейромережевий підхід iз використанням надбудови NeuroXL Classifier для програми Microsoft Excel. Програма NeuroXL Classifier реалізує самоорганізаційні нейромережі, що виконують категоріювання шляхом вивчення трендів та взаємозв'язків усередині даних. Ключовими перевагами використання NeuroXL Classifier $€$ простота при опануванні та використанні; необов'язковість поглиблених знань у галузі нейромереж; інтеграція з Microsoft Excel; надання обгрунтованої нейромережевої технології для високоточної класифікації; визначення взаємозв'язків і трендів, що неможливо визначити традиційними методами [1, 11-12].

Результати та їх обговорення. У досліджуваних групах визначали динаміку змінення таких морфометричних показників як пересічні діаметр і площа м'язових волокон, площа їхніх ядер, а також показник ядерно-цитоплазматичного співвідношення в ділянці середньої третини стегна щурів у різні періоди після зняття турнікета (табл. 1).

У всіх п'яти досліджуваних групах білих щурів проведено порівняльний аналіз пересічних показників вмісту в сироватці крові загального білка, тригліцеридів, креатиніну, холестерину, загального білірубіну, активності аланінамінотрансферази (АлАТ), аспартатамінотрансферази (АсАТ) та лужної фосфатази (ЛФ). Результати досліджень відображено в табл. 2.

При порівнянні морфометричних показників м'язових волокон із біохімічними показниками сироватки крові за допомогою кореляційного аналізу в досліджуваних групах виявлено слабкий або середньої сили прямий кореляційний зв'язок між показниками пересічної площі (ss) м'язових волокон та показниками креатиніну $(+0,1)$, холестерину $(+0,4)$, загального білірубіну $(+0,1)$, АлАТ $(+0,5)$, АсАТ $(+0,5)$ та ЛФ $(+0,1)$, а також слабкий зворотний кореляційний зв'язок між показниками пересічної площі (ss) м’язових волокон і рівнем тригліцеридів $(-0,1)$. Схожа закономірність виявлялася стосовно пересічної площі їхніх ядер. 


\section{Змінення пересічного діаметра $(\mathrm{d})$, площі $\left(\mathrm{S}_{\mathrm{S}}\right)$ та площі ядер $\left(\mathrm{S}_{\mathrm{n}}\right)$ м'язових волокон, ядерно-цитоплазматичного співвідношення $\left(\mathrm{S}_{\mathrm{n}} / \mathrm{S}_{\mathrm{S}}\right)$ в ділянці стегна щурів у різні періоди після зняття турнікета $(\mathrm{M} \pm \mathbf{m})$}

\begin{tabular}{|l|c|c|c|c|c|c|}
\hline \multicolumn{1}{|c|}{ Показник } & Контроль & $\begin{array}{c}\text { Реперфузія, } \\
\text { через 1 год }\end{array}$ & $\begin{array}{c}\text { Реперфузія, } \\
\text { через 2 год }\end{array}$ & $\begin{array}{c}\text { Реперфузія, } \\
\text { через 1 добу }\end{array}$ & $\begin{array}{c}\text { Реперфузія, } \\
\text { через 7 діб }\end{array}$ & $\begin{array}{c}\text { Реперфузія, } \\
\text { через } 14 \text { діб }\end{array}$ \\
\hline $\mathrm{d}, \mathrm{MKм}$ & $40,4 \pm 0,6$ & $40,8 \pm 0,8$ & $41,7 \pm 0,4^{*}$ & $41,7 \pm 0,4^{*}$ & $41,6 \pm 0,4$ & $40,8 \pm 0,4^{* *}$ \\
\hline $\mathrm{S}_{\mathrm{n}}, \mathrm{MKм}^{2}$ & $63,96 \pm 0,1$ & $63,98 \pm 0,1$ & $63,99 \pm 0,1$ & $64,03 \pm 0,1$ & $64,0 \pm 0,1$ & $63,8 \pm 0,1$ \\
\hline $\mathrm{S}_{\mathrm{S}}, \mathrm{MKM}^{2}$ & $1282,9 \pm 34,6$ & $1312,3 \pm 52,4$ & $1364,7 \pm 22,7^{*}$ & $1369,2 \pm 26,6 *$ & $1359,2 \pm 28,2$ & $1309,8 \pm 28,0 * *$ \\
\hline $\mathrm{S}_{\mathrm{n}} / \mathrm{S}_{\mathrm{S}}$ & $0,050 \pm 0,001$ & $0,050 \pm 0,002$ & $0,047 \pm 0,001^{*}$ & $0,047 \pm 0,001^{*}$ & $0,047 \pm 0,001$ & $0,049 \pm 0,001$ \\
\hline
\end{tabular}

Примітки: * — p <0,05 порівняно з групою контролю; ** - p <0,05 порівняно з третьою групою

Таблиця 2

\section{Змінення біохімічних показників у сироватці крові білих щурів у різні періоди після зняття турнікета $(\mathrm{M} \pm \mathrm{m})$}

\begin{tabular}{|l|c|c|c|c|c|c|}
\hline \multicolumn{1}{|c|}{ Показник } & Контроль & $\begin{array}{c}1 \text { група, } \\
\text { репер-фузія } \\
1 \text { год }\end{array}$ & $\begin{array}{c}2 \text { група, } \\
\text { реперфузія } \\
2 \text { год }\end{array}$ & $\begin{array}{c}3 \text { група, } \\
\text { реперфузія 1 } \\
\text { доба }\end{array}$ & $\begin{array}{c}4 \text { група, } \\
\text { реперфузія } \\
7 \text { діб }\end{array}$ & $\begin{array}{c}5 \text { група, } \\
\text { реперфузія } \\
14 \text { діб }\end{array}$ \\
\hline $\begin{array}{l}\text { Загальний } \\
\text { білок, г/л }\end{array}$ & $68,8 \pm 5,8$ & $61,2 \pm 2,8$ & $63,1 \pm 1,4$ & $58,9 \pm 2,1$ & $61,8 \pm 2,2$ & $60,8 \pm 2,8$ \\
\hline $\begin{array}{l}\text { Тригліцери- } \\
\text { ди, ммоль/л }\end{array}$ & $0,63 \pm 0,08$ & $0,61 \pm 0,05$ & $0,53 \pm 0,03$ & $0,52 \pm 0,04$ & $1,00 \pm 0,21$ & $0,72 \pm 0,08$ \\
\hline $\begin{array}{l}\text { Креатинін, } \\
\text { мкмоль/л }\end{array}$ & $53,6 \pm 1,5$ & $49,5 \pm 1,6$ & $45,5 \pm 1,5^{*}$ & $55,8 \pm 3,7$ & $49,5 \pm 1,5$ & $49,9 \pm 0,9$ \\
\hline $\begin{array}{l}\text { Холестерин, } \\
\text { ммоль/л }\end{array}$ & $1,6 \pm 0,1$ & $1,4 \pm 0,1$ & $1,5 \pm 0,2$ & $1,8 \pm 0,1$ & $1,4 \pm 0,1$ & $1,4 \pm 0,1$ \\
\hline $\begin{array}{l}\text { Загальний } \\
\text { білірубін, } \\
\text { мкмоль/л }\end{array}$ & $3,0 \pm 0,3$ & $5,0 \pm 0,6^{*}$ & $6,2 \pm 0,3^{* * *}$ & $3,9 \pm 0,3^{* * * *}$ & $3,7 \pm 0,4$ & $4,2 \pm 0,4$ \\
\hline АлАТ, од/л & $61,4 \pm 4,1$ & $65,1 \pm 7,2$ & $82,1 \pm 7,9 *$ & $116,4 \pm 8,3^{* * *}$ & $57,8 \pm 2,8^{* * * *}$ & $60,9 \pm 3,1$ \\
\hline АсАТ, од/л & $354,1 \pm 57,7$ & $563,8 \pm 58,3$ & $632,9 \pm 73,0^{* * *}$ & $598,8 \pm 55,1$ & $311,6 \pm 18,5^{* *}$ & $367,5 \pm 63,5$ \\
\hline ЛФ, од/л & $411,8 \pm 74,9$ & $425,1 \pm 133,3$ & $405,3 \pm 54,5$ & $528,05 \pm 39,1$ & $600,4 \pm 62,5$ & $488,5 \pm 18,1$ \\
\hline
\end{tabular}

Примітки: * - p<0,05 порівняно з групою контролю; ** - p<0,05 порівняно 3 попередньою групою; *** — $<<0,005$ порівняно з групою контролю; **** $-\mathrm{p}<0,005$ порівняно з попередньою групою

Спостерігався прямий кореляційний зв'язок середньої сили між показниками пересічної площі ядер (sn) м'язових волокон та показниками креатиніну $(+0,3)$, холестерину $(+0,6)$, АлАТ $(+0,6)$, AcAT $(+0,3)$ та ЛФ $(+0,3)$, та слабкий зворотний кореляційний зв’ язок між показниками пересічної площі ядер м'язових волокон(sn) і рівнем тригліцеридів $(-0,1)$.

3 метою встановлення значення поєднаних змін тих чи інших параметрів для прогнозування розвитку ішемічно-реперфузійних пошкоджень було здійснено нейромережеву кластеризацію результатів біохімічного аналізу (рис. 1) на основі показників сироватки крові білих щурів у різні періоди після зняття турнікету: Protein - загальний білок (1), TrGlc - тригліцериди (2), Creatinin - креатинін (3), Cholest - холестерин (4), ComBilir - загальний білірубін (5), ALT - АлАT (6), AST - AcAT (7), AF — лужна фосфатаза (8), та S - тяжкість, вираженість 
морфологічних змін у різні періоди після зняття турнікету (9). При цьому показник S визначався щодо кожної піддослідної тварини як «4» у випадку взяття матеріалу для дослідження через 1 добу після накладання турнікета, «3» - через 2 години, «2» — через 1 годину та «1» — без накладання турнікету (контроль).

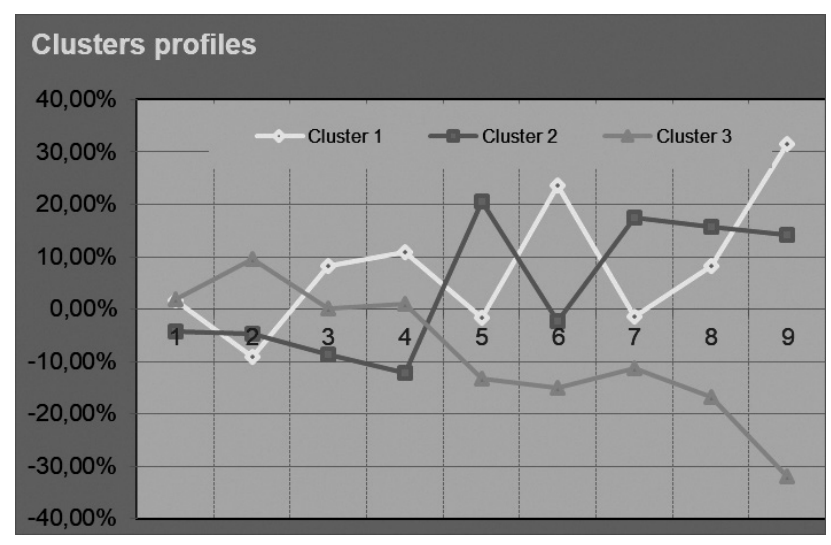

a)
Для алгоритму нейромережевої кластеризації обрано параметри, запропоновані програмою, та кількість кластерів, рівну п’ятьом. На рис. 1а, б наведено результати виконання програмою кластеризації показників дослідження тварин різних груп. До першого та другого кластерів належить по 29,2 \% піддослідних тварин, а до третього —-41,7 \% тварин.

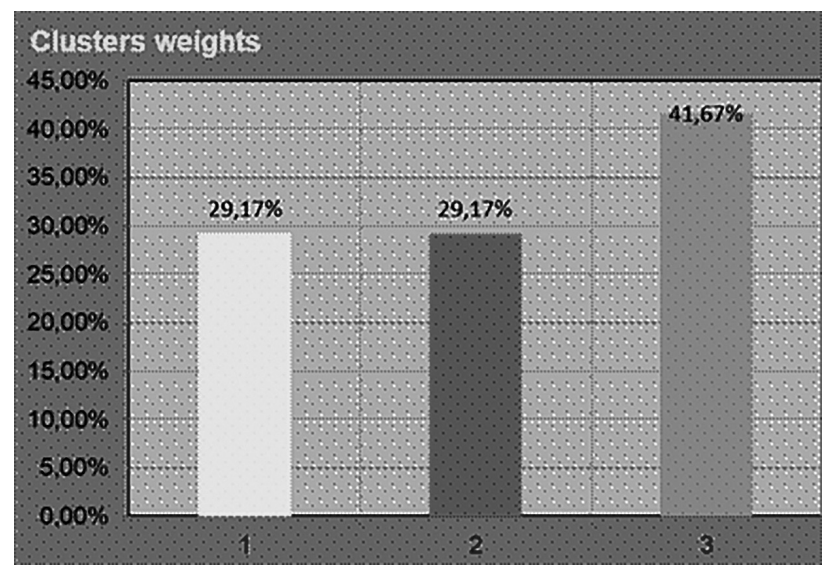

б)

Рис. 1. Результати кластеризації біохімічних показників сироватки крові піддослідних тварин у різні періоди розвитку ішемії-реперфузії: а) кластерний портрет - значення параметрів, включно із біохімічними показниками та показником вираженості морфологічних змін у різні періоди після зняття турнікету; б) частки кластерів — відсотки піддослідних тварин, які потрапили в певний кластер

Найнижче значення показника вираженості морфологічних змін у задніх кінцівках щурів при розвитку ішемії-реперфузії (S) виявлялося у третьому кластері, а найвище - в першому кластері. При цьому за допомогою кластерного портрета можна визначити, що на перший кластер припали і найвищі показники креатиніну (Creatinin, 3), холестерину (Cholest, 4) та АлAT (ALT, 6).

Висновки. 1. Для оптимізації прогнозування розвитку морфологічних ішемічних порушень при експериментальній гострій ішемії-реперфузії запропоновано методику аналізу результатів експериментального дослідження на основі середніх значень морфологічних і біохімічних показників, коефіцієнтів кореляції та нейромережевої кластеризації.

2. При порівнянні морфометричних показників м'язових волокон із біохімічними показниками сироватки крові за допомогою кореляційного аналізу виявлено середньої сили прямий кореляційний зв'язок між показниками пересічної площі м'язових волокон і показниками аланінамінотрансферази $(+0,5)$ та аспартатамінотрансферази $(+0,5)$, що свідчить про переважання у м'язовій тканині процесів катаболізму за умов розвитку ішемічнореперфузійного пошкодження.

3. За результатами застосування нейромережевої кластеризації найбільше прогностичне значення щодо тяжкості морфологічних порушень у ранньому реперфузійному періоді мають поєднані зміни рівня креатиніну та аланінамінотрансферази.

Бачиться перспективним запровадження поєднаного використання кореляційного аналізу та нейромережевої кластеризації при роботі зі значною за обсягом цифровою інформацією для прогнозування розвитку патологічних процесів із метою та подальшого прикладного використання на практиці. 


\section{Література.}

1. Трансформування знань з атерогенезу: використання наноасоційованих біотехнологій і мережевого аналізу / Мінцер О. П., Заліський В. М. // Медична інформатика та інженерія. — 2019. № 1. - C. 424.

2. On an algorithm for decision-making for the optimization of disease prediction at the primary health care level using neural network clustering / P. R. Selskyy, D. V. Vakulenko, A. T. Televiak, T. O. Veresiuk // Family Medicine \& Primary Care Review. - 2018. — Vol. 20, № 2. - P. 171-175.

3. Measuring patient-centered communication in patientphysician consultations: theoretical and practical issues / R.M. Epstein, P. Franks, K. Fiscella et al. // Soc. Sci. Med. - 2005. - Vol. 61. - P. 1516-1528.

4. Death on the battlefield (2001-2011): implications for the future of combat casualty care / B. J. Eastridge, R. L. Mabry, P. Seguin et al. // J. Truma Acute Care Surg. — 2012. - Vol. 73. - P. 431-437.

5. Current Mechanistic Concepts in Ischemia and Reperfusion Injury / M.-Y. Wu, G.-T. Yiang, W.-T. Liao, A. P.-Y. Tsai, et al. // Cell Physiol. Biochem. — 2018. - Vol. 46. - P. 1650-1667.

6. Different oxidative stress marker levels in blood from the operated knee or the antecubital vein in patients undergoing knee surgery: a tourniquet-induced ischemia-reperfusion model / J. Garcia-de-la-Asuncion, A. Perez-Solaz, M. Carrau et al. // Redox Report. 2013. - Vol. 17, № 5. - P. 194-199.

7. Клінічно-організаційні особливості надання травматологічної допомоги пораненим із дефектами м’яких тканин при вогнепальних та мінно-вибухових ушкодженнях кінцівок / Хоменко І. П., Король С. О., Матвійчук Б. В. // Травма. - 2018. - Т. 19, № 5. - С. 125-129.

8. Результати лікування хворих із гострою артеріальною ішемією кінцівок / Губка В. О., Коноваленко І. А., Суздаленко О. В. // Патологія. — 2015. — № 2 (34). - C. 55-58.

9. The effect of ischemia reperfusion injury on skeletal muscle / S. Gillani, J. Cao, T. Suzuki, D. // J. Hak. Injury. — 2012. — Vol. 43, № 6. — P. 670-675.

10. Основи гістологічної техніки і морфофункціональні методи досліджень у нормі та при патології / Горальський Л. П., Хомич В. Т., Кононський О. І. - Житомир: Полісся, 2011. - 288 с.

11. Neural Networks for Pattern Recognition / Bishop C. M. - Oxford: Oxford University Press. 1995. — 504 p.

12. Clustering: A neural network approach / Du K. L. // Neural network. — 2010. — Vol. 23, № 1. — P. 89-107.

\section{References.}

1. Mintser, O. P., Zaliskyi, V. M. (2019). Transformuvannia znan z aterohenezu: vykorystannia nanoasotsiiovanykh biotekhnolohii i merezhevoho analizu. [Transformation of knowledge of atherogenesis: the use of nanoassociated bio-technologies and network analysis]. Medychna informatyka ta inzheneriia. 1, 424.

2. Selskyy, P. R., Vakulenko, D. V., Televiak, A. T., Veresiuk, T. O. (2018). On an algorithm for decision-making for the optimization of disease prediction at the primary health care level using neural network clustering. Family Medicine \& Primary Care Review, 20 (2), 171-5.

3. Epstein, R. M., Franks, P., Fiscella, K., Shields, C. G., Meldrum, S. C, Kravitz, R. L., Duberstein, P. R. (2005). Measuring patient-centered communication in patientphysician consultations: theoretical and practical issues Soc. Sci. Med., 61, 1516-28.

4. Eastridge, B. J., Mabry, R. L, Seguin, P, Cantrell, J. et al. (2012). Death on the battlefield (2001-2011): implications for the future of combat casualty care. $J$. Truma Acute Care Surg., 73, 431-7.

5. Wu, M. Y., Yiang G. T., Liao, W. T. et al. (2018). Current Mechanistic Concepts in Ischemia and Reperfusion Injury. Cell Physiol. Biochem., 46, 1650-67.

6. Garcia-de-la-Asuncion, J., Perez-Solaz, A., et al. (2013). Different oxidative stress marker levels in blood from the operated knee or the antecubital vein in patients undergoing knee surgery: a tourniquet-induced ischemia-reperfusion model. Redox Report., Vol. 17 (5), 194-9.

7. Khomenko, I. P., Korol, S. O., Matviichuk, B. V. (2018). Klinichno-orhanizatsiini osoblyvosti nadannia travmatolohichnoi dopomohy poranenym iz defektamy miakykh tkanyn pry vohnepalnykh ta minnovybukhovykh ushkodzhenniakh kintsivok. [Clinical and organizational peculiarities of traumatological care for the injured with soft tissue defects in inflammatory and mine-explosive injuries of the extremities]. Travma, 19 (5), 125-9. [In Ukrainian].

8. Hubka, V. O., Konovalenko, I. A., Suzdalenko, O. V. (2015). Rezultaty likuvannia khvorykh iz hostroiu arterialnoiu ishemiieiu kintsivok. [Results of treatment of patients with acute arterial ischemia of extremities]. Patolohiia, 2 (34), 55-8. [In Ukrainian].

9. Gillani, S., Cao, J. , Suzuki, T., Hak, D. J. (2012). The effect of ischemia reperfusion injury on skeletal muscle. Hak. Injury, 43 (6), 670-5.

10. Horalskyi, L. P., Khomych, V. T., Kononskyi, O. I. (2011). Osnovy histolohichnoi tekhniky i morfofunktsionalni metody doslidzhen u normi ta pry patolohii. [Fundamentals of histological technique and morphofunctional methods of research in normal and pathology]. Polissia, Zhytomyr: 288. [In Ukrainian].

11. Bishop, C. M. (1995) Neural Networks for Pattern Recognition. Oxford: Oxford University Press., 504.

12. Du, K. L. (2010). Clustering: A neural network approach. Neural network, 23 (1), 89-107. 